\title{
Hymenolepis dimunata Infection in a Child of 14 month
}

\author{
Thakur NK, ${ }^{1}$ Mishra SK, ${ }^{2}$ Neupane GP, ${ }^{1}$ J ha A $^{3}$ \\ ${ }^{1}$ Department of Microbiology, Kathmandu University School Medical School, Dhulikhel, Kavre, ${ }^{2}$ Department of Public \\ Health/ Biochemistry, National Academy for Medical Sciences, Baneshwor, Kathmandu, 3Department of Pediatrics, \\ Kathmandu University School Medical School, Dhulikhel, Kavre
}

\begin{abstract}
We report a case, a 14 month old male child who presented with fever and diarrhea for a month. It was diagnosed as a case of $\mathrm{H}$ dimunata infection, which is a sole parasite of rat. Very few cases of such infection have been reported in Nepal. The treatment is done with either Niclosamide or Praziquantel, but the main concern is about the diagnosis of the condition. Since, $\mathrm{H}$ dimunata is a sole rat parasite, it is hardly ever thought about a cause of the diarrhea.

Key words: Diarrhea, $H$ dimunata, Niclosamide
\end{abstract}

\section{INTRODUCTION}

H. dimunata (rat tapeworm) is a sole parasite of rat and it rarely parasitizes human. Its scolex has an unarmed rostellum and four suckers. ${ }^{1,2,3}$ The number of proglottids varies from 800 to 1000 . It has a worldwide distribution in normal hosts. ${ }^{1,2,3}$ Cases have been reported from Belgium, Italy, U.S.S.R, J apan, China, Philippines, India, Africa, Argentina, Brazil, Venezuela, Colombia, Ecuador, Granada, Martinique, Nicaragua, Cuba, and United states.

However, this infection is uncommon in Nepal, according to a survey done on Human Parasite Infection in Nepal in 1985. The first case was reported in $1965 .{ }^{4}$ Earlier report had found a case in J iri, a hilly district. ${ }^{5}$ Thus we present another case of this rare infection by $\mathrm{H}$. dimunata.

\section{CASE REPORT}

A 14 month old male child from Udayapur, presented with high grade fever $\left(102^{\circ} \mathrm{F}\right)$ with sweating but no rigors. He also had mild cough. He had a history of mild diarrhoea, abdominal pain, indigestion, and anorexia for a month. He also had one episode of loss of consciousness with up rolling of eyes, abnormal movements and stiff body. There was no history of febrile seizures or such episodes in past. He was found normal during physical examination. His leukocyte count was $8800 /$ cc, with $6 \%$ eosinophils and hemoglobin $13.8 \mathrm{gm} / \mathrm{dl}$. No abnormality was detected in urine examination. The parasitological examination of the stool specimen revealed spherical body with striated outer membrane, approximately 65 $\mu \mathrm{m}$ in diameter, thick shelled eggs that contained six central hooklets but no polar filaments. They were confirmed as the ova of Hymenolepis dimunata. He was given oral Niclosamide; 2 gm (four tablets) as the first dose and subsequent five doses (i.e., days 2 through 6) were reduced to $1 \mathrm{gm}$ daily. One month after completion of the treatment, he turned asymptomatic and subsequent parasitological examination showed no ova of $\mathrm{H}$. dimunata Additional examination carried out three months after treatment was also found negative.

Correspondence: Mr. Nabin Kumar Thakur, Department of Microbiology, Kathmandu University School Medical School, Dhulikhel, Kavre, Nepal. Email: nabinkumar_thakurmr@yahoo.com 
Hymenolepis dimunata Infection in a Child of 14 month
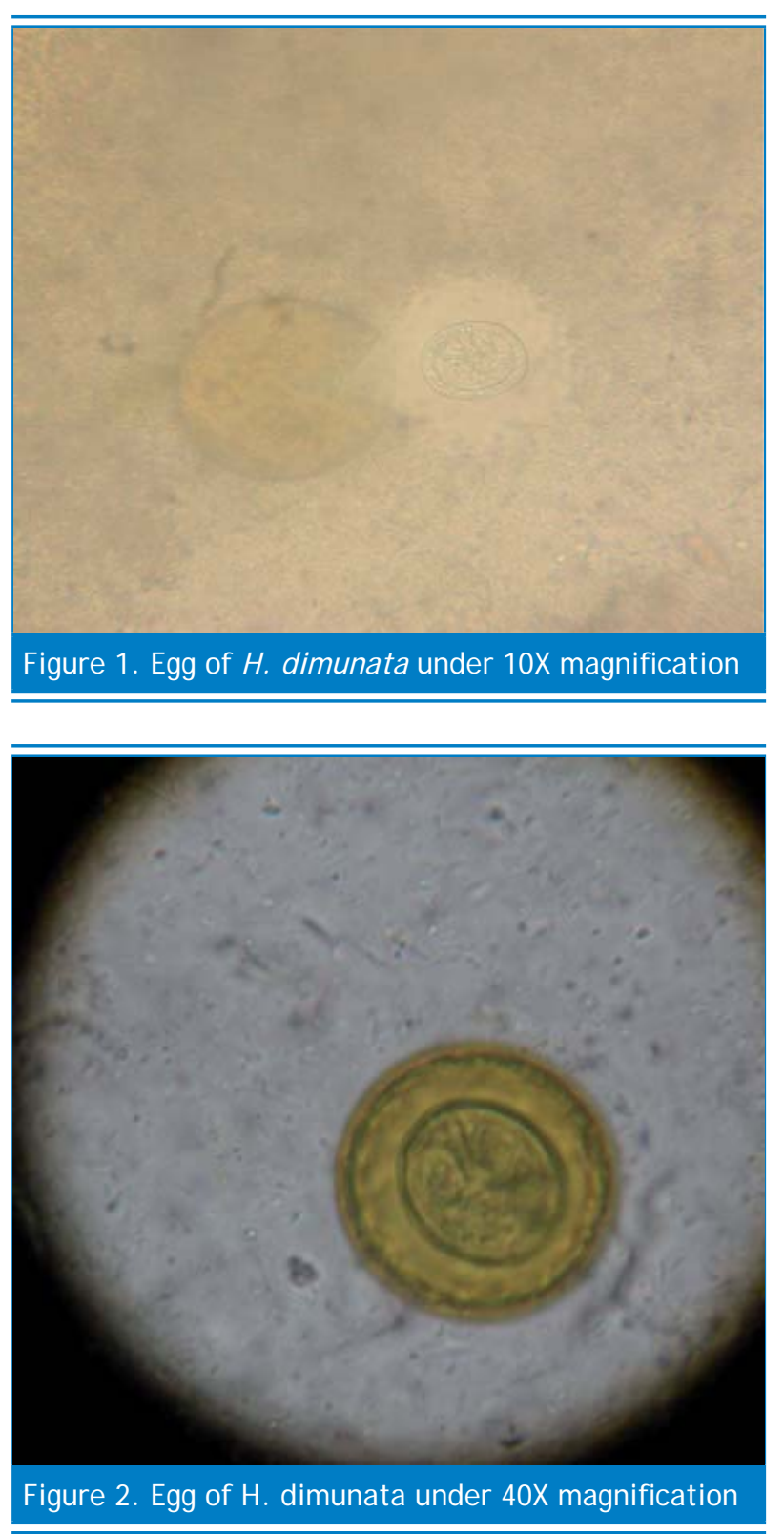

\section{DISCUSSION}

Hymenolepis dimunata (rat tapeworm), a sole parasite of rat, rarely parasitize human. It is relatively larger species than Hymenolepis nana. Approximately 200 human cases, so far primarily from India, the former Soviet Union, Japan and certain areas of the southern United States have been reported. 6, 7, 8

Several human cases in children living in the urban area of Rome from Italy ${ }^{9}$, and from Spain ${ }^{10}$ in 1998 have also been published. A case of Hymenolepis dimunata infection in human adult was also reported in Nepal $2005 .^{5}$

It is often asymptomatic, however, mild diarrhoea, abdominal pain, irritability and pruritus have been associated with this condition. However, it may cause eosinophilia, a finding that was also present in this case. Though intestinal parasitic infection in our country, Nepal, is common ${ }^{11}$ the diarrhoeal disease due to $\mathrm{H}$. dimunata was not reported and published before 2005 .

Rats and other rodents are the principal definitive hosts and natural reservoir of $\mathrm{H}$. diminuta. ${ }^{1,2,3}$ Cockroaches, beetles, fleas and other coprophilic arthropods are the intermediate hosts. ${ }^{1,2,3}$ Foods such as beaten rice and cereals contaminated with infected arthropods are the chief sources of infection. Beaten rice is very popular snack among children in this region and equally consumed in his home. The most likely way that this boy contracted infection was to have eaten arthropods containing the infective stages of the species. Usually children appear to be more prone to infection by this species. ${ }^{9}, 10,12,13,15$

Safe and effective treatment of $\mathrm{H}$. diminuta infection can be achieved with either Praziquantel or Niclosamide. ${ }^{14}$ Though the drug of choice for this tapeworm is Praziquantel, we used Niclosamide because of its easy availability in this region and efficacy. The present case report in this area confirms the distribution of this species in Nepal and also that the infectious agent can infect adult as well as children. Presence of clear symptoms and the condition of the patient in this case tends to support that the infection with $\mathrm{H}$. dimunata may give rise to significant gastrointestinal illness in humans. Elimination of $\mathrm{H}$. dimunata requires appropriate anti-helminthic treatment and it is better to re-screen the patient's stool for parasitic eggs at one and three months after therapy to ensure cure.

\section{CONCLUSION}

Thus, $\mathrm{H}$ dimunata infection should also be considered as a possibility among children presenting with a history of diarrhea for some period. Appropriate investigations should be done to rule out or confirm the diagnosis.

\section{REFERENCES}

1. Baily GC. Intestinal Cestodes. In: Cook GC, editor. Manson's Tropical Diseases. 10th ed. London: WB Saunders Company; 1996.

2. Garcia LS, and Bruckner DA. Diagnostic Medical Parasitology. 3rd ed. Washington DC: ASM Press; 1997.

3. King CH. Cestodes. ln: Mandell GL, Bennet JE and Dolin R, editors. Principles and Practice of Infectious Diseases. New York: Churchill Livingstone; 1995.

4. Ratliff RC and Donalson LA. Human Case of Hymenolepis diminuta.J. Parasitol.1965;51:808.

5. Kunwar CB, Subba B, Shrestha M, Chapagain RH, Jha B, Subedi 
$\mathrm{J}$, et al. A human case of Hymenolepis diminuta infection in Nepal. Journal of Institute of Medicine 2005; 27:66-67.

6. Garcia LS, Bruckner DA. Diagnostic Medical Parasitology. 3rd ed. Washington DC: ASM Press; 1997.

7. King CH. Cestodes. In: Mandell GL, Bennet JE and Dolin R, editors. Principles and Practice of Infectious Diseases. New York: Churchill Livingstone; 1995.

8. Edelman MH, Springarn CL, Nauenberg WG and Gregory C. Hymenolepis diminuta (rat tapeworm) infection in man. Am.J.Med. 1965;38:951.

9. Marangi M, Zechini B, Fileti A, Quaranta G and Aceti A. Hymenolepis diminuta Infection in a Child Living in the Urban Area of Rome, Italy. J Clin Microbiol. 2003;41:3994-5.

10. Tena DS, Gimeno MP, Pomata C, et al. Human Infection with Hymenolepis diminuta: Case Report from Spain. J Clin.Microbiol. 1998;36:2375-6.
11. Sugari S, ToonguY, Inatomi S, Pradhan HD. A Survey on Human Parasite Infection in Nepal. Japanese Journal of Parasitiology 1985;34:285-91

12. Machado ER and Costa CJM. Strongyloides stercoralis and Other Enteroparasites in Children at Uberlandia City, State of Minas Gerais, Brazil. Mem. Inst. Oswaldo Cruz. 1998;93:161-4.

13. Hamrick HJ, Bowdre JH and Church SM. Rat tapeworm (Hymenolepis diminuta) infection in a child. Pediatr. Infect. Dis. J. 1990;9:216-9.

14. Beaver PC, Jung RC and Cupp FW. Clinical Parasitology. 9th ed. Philadelphia: Lea and Febiger; 1984.

15. Levi MH, Raucher BG, Teicher E, Sheehan DJ and Mckitrick JC. Hymenolepis diminuta: One of three enteric pathogens isolated from a child. Diagn. Microbiol. Infect. Dis. 1987;7:255-9. 